\title{
Effect of Wood Species, Adhesive Type, and Annual Ring Directions on the Stiffness of Rail to Leg Mortise and Tenon Furniture Joints
}

\author{
Vladimír Záborský,* Vlastimil Borůvka, Václava Kašičková, and Daniel Ruman
}

The effects of selected factors, wood species (Fagus sylvatica L. and Picea abies L.), type of joint (haunched mortise and tenon, and haunched dovetail mortise and tenon), tenon thickness (one-third and half-joint thickness), type of adhesive (polyvinyl acetate and polyurethane adhesive), loading type (compressive and tensile), and direction of the annual rings were evaluated relative to the elastic stiffness. The testing samples were loaded by bending moment with tensile and compressive forces in the angular plane. The wood species, type of joint, tenon dimension, and type of adhesive all had a statistically significant effect on the elastic stiffness. However, the interaction of those factors was statistically insignificant. The loading type and direction of the annual rings did not have a significant effect on the elastic stiffness. For spruce, the use of mortise and tenon with a toothed feather (MTTF) was found to be disadvantageous, whereas the use of a toothed feather was favorable for beech. Half thickness of the joint was always an advantage, such that the stiffness increased. For spruce joints, the type of glue was not important, whereas for beech, the stiffness of joints glued with PVAc was significantly higher than with PUR adhesive.

Keywords: Furniture wood joints; Mortise and tenon; Elastic stiffness

Contact information: Department of Wood Processing, Czech University of Life Sciences in Prague, Kamýcká 1176, Praha 6 - Suchdol, 16521 Czech Republic;

* Corresponding author: zaborsky.vladimir123@gmail.com

\section{INTRODUCTION}

When designing wooden structures and furniture, it is very important to consider joints that will allow the structure to stay together and upright. There are many different ways to join two pieces of wood together. Joints can be implemented by hand or by machine. Slicing (longitudinal joint), connecting (corner joint), and miscellaneous joint types (Sumiyoshi and Matsui 1989) all have different effects. The use of the proper joint type simplifies the structure and boosts its integrity (Sabareth 2014; Svoboda et al. 2015; Kubš et al. 2016). Many factors have to be considered when choosing the joint type (Sumiyoshi and Matsui 1989; Kvietková et al. 2015a,b). Joint structures need to be free from cracks, knots, wanes, and other defects that could affect the reliability of the connection and its stiffness (BS EN 789:2004). This study investigates which factors significantly affect the stress and strain in the structure and its stiffness.

Demountable (glue-free) and non-demountable (glued) joints have a different effect on the structure. According to the wood joint type, the appropriate fasteners and mounting aids, such as lamellas, dowels, screws, etc. (Nutsch et al. 2006), were used. Joint type selection is among one of the most important design parameters. It is often crucial to any 
type of wooden structure, such as wooden bridges, furniture construction, picture framing, and guitar skeletons. Joints represent a critical area of a structure (Noll 2009; Horman et al. 2010; Gaff et al. 2016). Horman et al. (2010) used the finite element method to confirm that the individual joint strength has significant influence on the stiffness of the whole chair construction. This research investigates the properties of the most widely used joint, mortise and tenon, and its variations.

Mortise and tenon joints have been used in furniture construction for years (Kasal et al. 2013; Miftieva et al. 2016), and there are interesting variations of this joint. Mortise and tenon can be done traditionally (straight variation) or it can be cross shaped, right angle shaped, or blind tenon and mortise spliced; however, the last variation is technically difficult (Sumiyoshi and Matsui 1989). The geometry of the mortise and tenon appears to be a significant strength parameter (Tankut and Tankut 2005). Kasal et al. (2015) examined the mortise and tenon joint strength of a chair made from Turkish beech (Fagus orientalis Lipsky), and investigated the relationship between the strength of a whole chair and the individual joints. The results of the research confirmed that the static loading capacity of a chair can be predicted from the bending capacities of individual joints (Kasal et al. 2015). Tankut and Tankut (2005) examined round and rectangular shaped mortise and tenon joints. As the width and length of the mortise and tenon increased, the strength of the joint improved correspondingly. Joints need to be well shaped and perfectly functioning. Oktaee et al. (2014) demonstrated that the greatest joint strengths are obtained when a close fit is maintained between the mortise and tenon (Tankut 2007; Kasal et al. 2013; Ruman et al. 2016).

A numerical investigation using the finite element method was used by Kasal et al. (2016), and mortises and tenons with different widths and lengths were simulated. The simulated joints became stronger and stiffer with increasing widths and lengths. The same results were obtained from the research conducted by Erdil et al. (2005), whose investigation examined T-shaped mortise and tenon joints made from red oak, sugar maple, walnut, and tulip poplar.

Mortise and tenon joints are typically glued. The effect of the adhesive type and moisture content on the strength of mortise and tenon joints was studied in the research of Tankut (2007), but no significant results were observed. With the development of science and technology in the industry, gluing joints has become more widely practiced (Sedliačik and Sedliačik 1998). Glued joints dampen vibrations in the structure and increase the stiffness. Glue can be transparent or colored depending on the desired design purpose (Osten 1996).

Oktaee et al. (2014) examined the geometry of a mortise and tenon joint for specimens made from Fagus orientalis Lipsky. A simple mortise and tenon was compared with a haunched tenon. Oktaee et al. (2014) also compared a simple and haunched tenon of the same thickness, and the stiffness values were found to be similar. The length of the tenon had the greatest effect on the moment capacity, and was usually breached in the adhesive.

The main approach of this research was to determine the factors with the highest impact on the joint stiffness and to identify parameters that had no impact. This approach was also used to deepen the theoretical knowledge about furniture joints. Such information could be useful in furniture design and manufacturing.

Within the experiments, the testing samples of joints were loaded with bending moment by applying tensile and compressive forces. The final goal of the research, which was regarded as a priority, was to evaluate the stiffness of the joints. 


\section{EXPERIMENTAL}

\section{Materials}

Spruce (Picea abies L.) and beech (Fagus sylvatica L.) specimens were used for the experimental testing. Logs from the region of Prešov in eastern Slovakia were sawed into beams that were acclimatized in an APT Line II climatic chamber (Binder, Tuttingen Germany) to an equilibrium moisture content of 10\%. According to ČSN EN 942 (2007), ČSN 910001 (2007), and ČSN 910000 (2005), this moisture content corresponds to the equilibrium moisture content of furniture components intended for indoor environments. The acclimatization was performed at $20{ }^{\circ} \mathrm{C}$ with a relative humidity of $55 \%$. The beams were then levelled to an exact thickness. CNC machine). Two types of joints were produced, a haunched mortise and tenon (MT), and haunched dovetail (toothed feather) mortise and tenon (MTTF). Figures 1 through 4 show the parts of a haunched mortise and tenon, and Figs. 5 through 8 show the technical drawings of the haunched dovetail mortise and tenon.

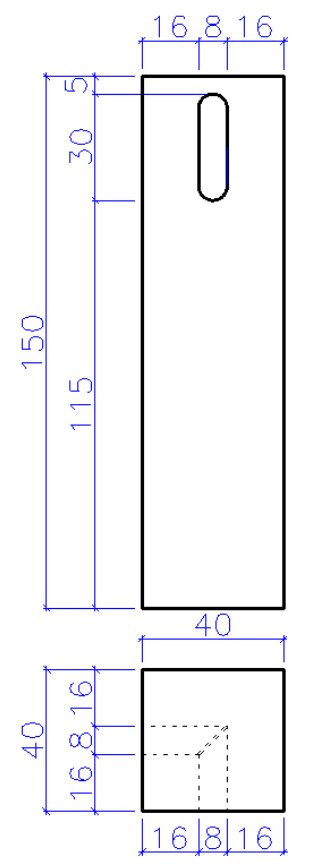

Fig. 1. Leg with 8-mm mortise

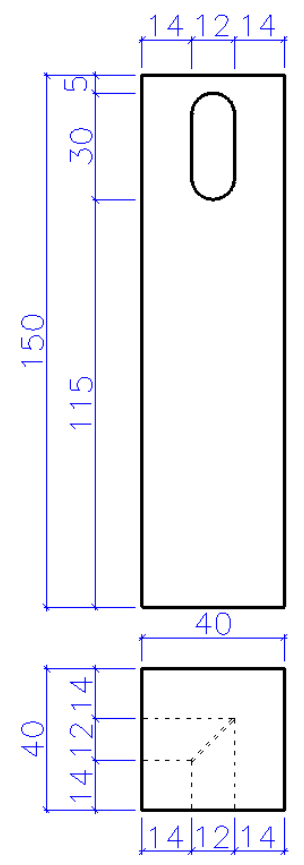

Fig. 2. Leg with 12-mm mortise

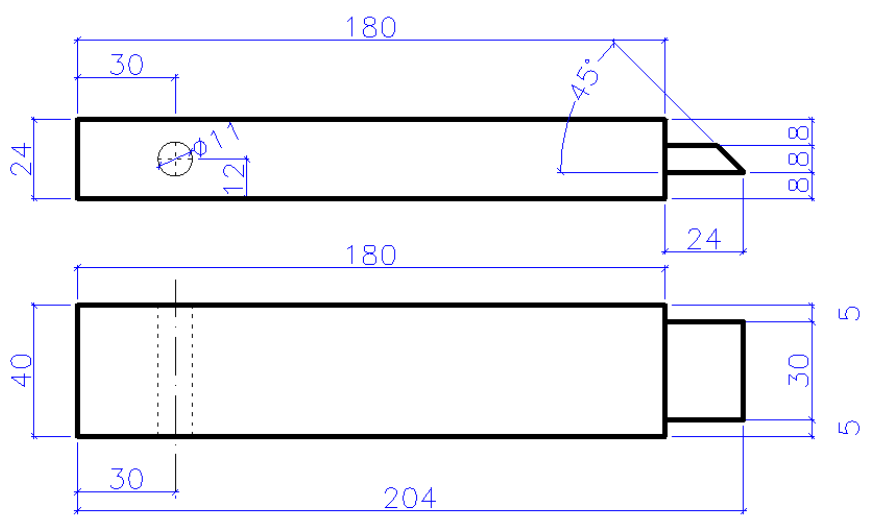

Fig. 3. Rail with 8-mm tenon 


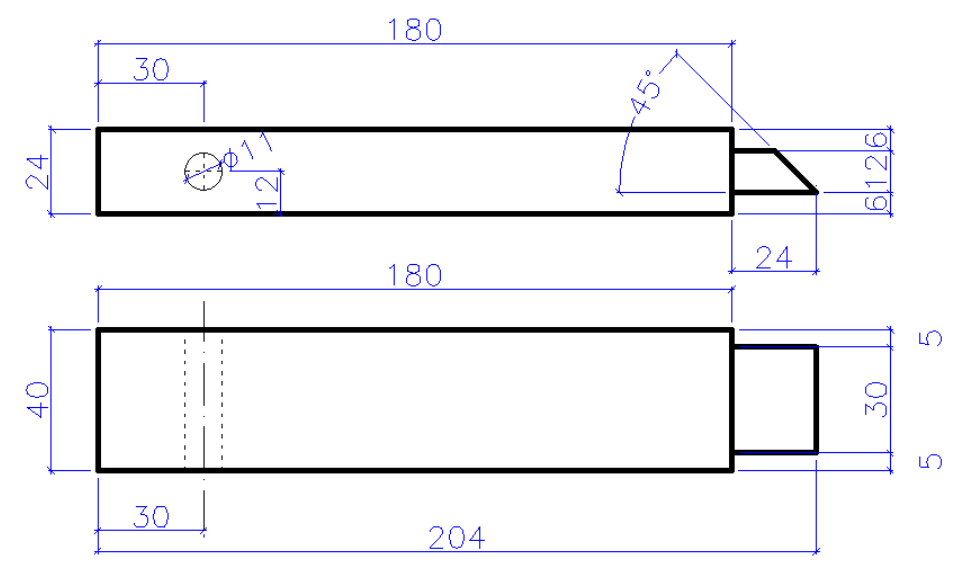

Fig. 4. Rail with 12-mm tenon

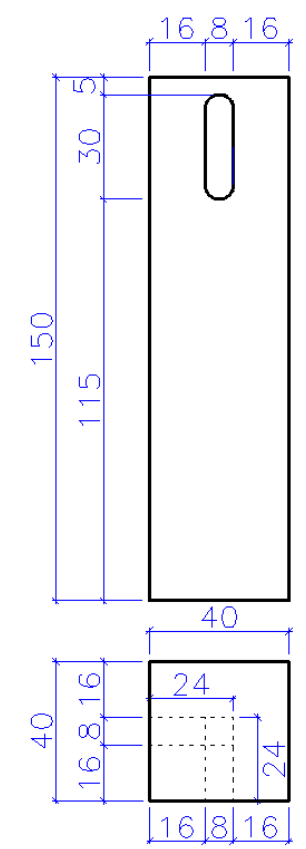

Fig. 5. Rail with 8-mm mortise

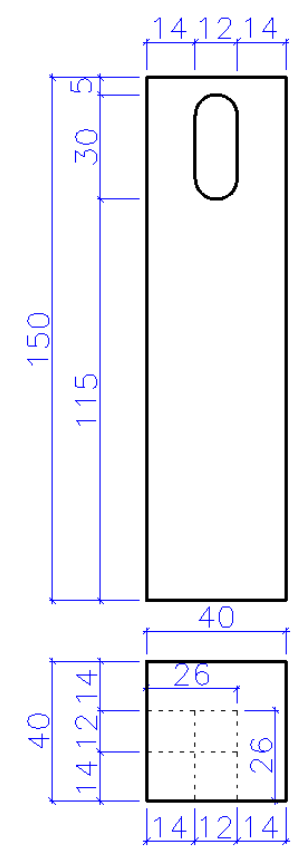

Fig. 6. Rail with 12-mm mortise

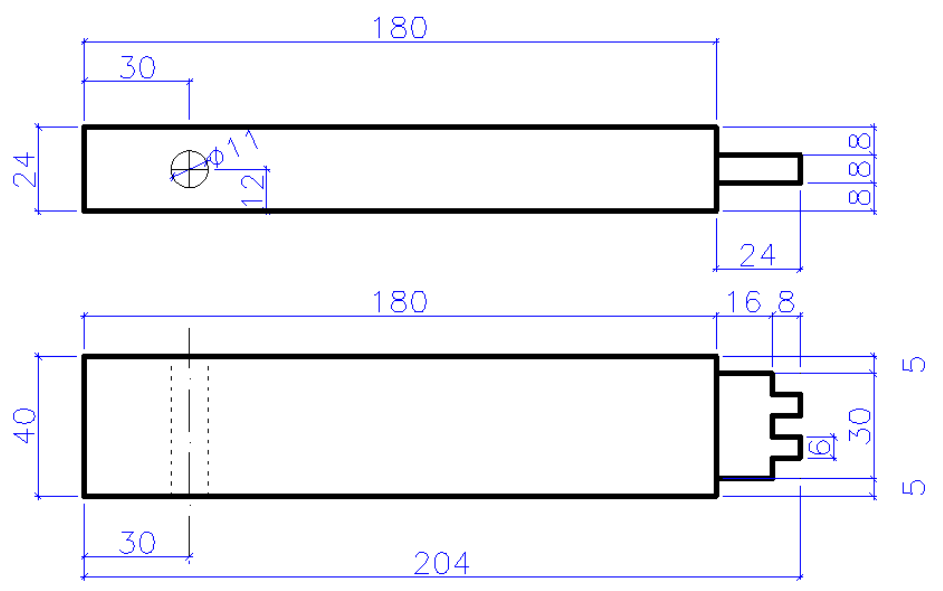

Fig. 7. Rail with $8 \mathrm{~mm}$-tenon with dovetail 


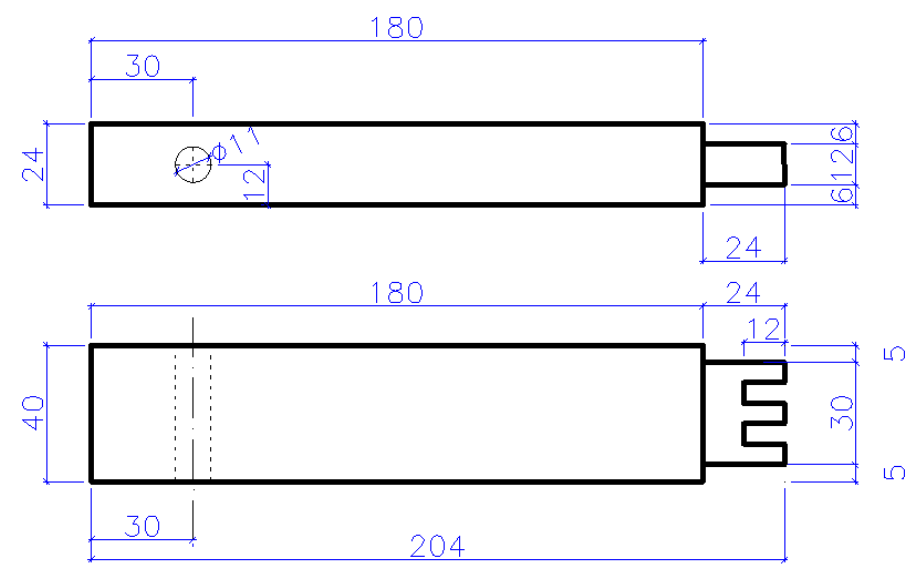

Fig. 8. Rail with 12-mm tenon with dovetail

In both types of joint, the mortises and tenons were glued, and two types of adhesives were used: polyvinyl acetate glue (PVAc) AG-COLL 8761/L D3 (EOC, Oudenaarde, Belgium) and polyurethane glue (PUR) NEOPUR 2238R (NEOFLEX, Madrid, Spain). The parameters of the adhesives are listed in Table 1. The glue was applied on both sides of the mortise and tenon manually with a brush. The PVAc adhesive type AG-COLL 8761/L D3 (EOC; Oudenaarde, Belgium) coating was $150 \mathrm{~g} / \mathrm{m}^{2}$ to $180 \mathrm{~g} / \mathrm{m}^{2}$, and the PUR glue coating was $180 \mathrm{~g} / \mathrm{m}^{2}$ to $250 \mathrm{~g} / \mathrm{m}^{2}$. To create the necessary cold pressing pressure, a JU 60 industrial press (PAUL OTT, Vienna, Austria) was used with a pressing duration of $60 \mathrm{~min}$. After pressing, the test specimens were acclimatized in an APT Line II climatic chamber at a temperature of $20{ }^{\circ} \mathrm{C}$ with a relative humidity of $55 \%$.

Table 1. Parameters of the PVAc and PUR Adhesives

\begin{tabular}{|c|c|c|}
\hline Technical Data & AG-COLL 8761/L D3 & NEOPUR 2238R \\
\hline Viscosity $(\mathrm{mPa})$ & 5000 to 7000 at $23^{\circ} \mathrm{C}$ & 2000 to 4500 at $25^{\circ} \mathrm{C}$ \\
\hline Working time $(\mathrm{min})$ & $15-20$ & 60 \\
\hline Density $\left(\mathrm{g} / \mathrm{cm}^{3}\right)$ & $0.9-1.1$ at $23{ }^{\circ} \mathrm{C}$ & $\sim 1.13$ \\
\hline NCO content $(\%)$ & - & $\sim 15.5$ to 16.5 \\
\hline Color & white, milk & Brown \\
\hline Open time $(\mathrm{min})$ & 15 & $\sim 20$ to 25 \\
\hline Dry matter content $(\%)$ & 49 to 51 & 100 \\
\hline $\mathrm{pH}$ & 3.8 to 4.5 & - \\
\hline
\end{tabular}

The evaluated factors of the joint stiffness were two types of wood species (beech and spruce), two types of furniture joints (simple mortise and tenon, and dovetail mortise and tenon), two tenon dimensions (one-third and half-joint thickness), two types of adhesives (PVAc and PUR), and two types of stress (compression and tension). The number of examined factors resulted in 32 combinations, where 10 pieces of test joints were examined for each combination. A total of 320 joint pieces were produced for this study.

The annual ring direction was also evaluated as a factor. An illustration of the approach used is provided in Fig. 9. This factor is more or less secondary, and was only observed in a complementary way, with some types of variations in the larger research being more significant. For example, it showed a lower variability of stiffness with 90 degree deflection. 


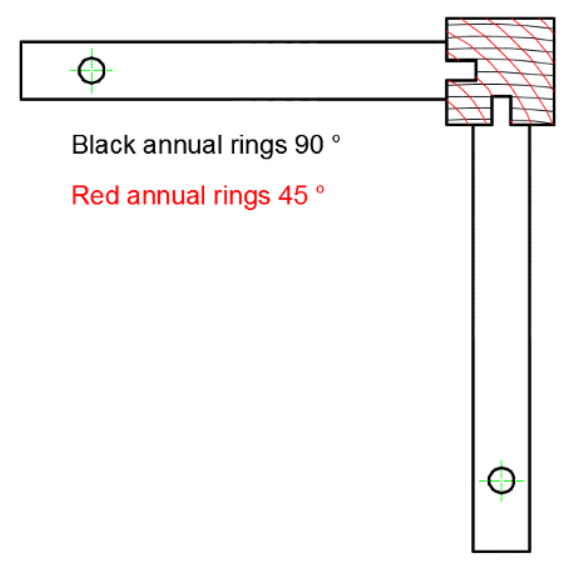

Fig. 9. Schematic illustration of fiber deflection (Záborský et al. 2017)

\section{Methods}

The moisture content of the samples was determined and verified before and after testing. These calculations were performed according to ISO 13061-1:2014 (2014). The wood density was determined according to ISO 13061-2:2014 (2014).

A TIRA 50 universal testing machine (TIRA GmbH, Schalkau, Germany) was used for the experimental testing of the joints with tensile and compressive stress. Figure 10A shows a diagram of the tensile and compressive test that was used for both types of joints. The original shape before loading is displayed in black, and the deformed state is shown in purple. The rails were connected using steel fixtures with rotating steel tenons with a diameter of $10 \mathrm{~mm}$, which were inserted into the holes in the joint rail (Fig. 10B). During the experimental test, the change in the distance between the steel pins of the fixture $(\mathrm{L} \rightarrow$ $\left.L^{\prime}\right)$ was evaluated, from which the arcsine function $(\gamma)$ in radians was calculated.

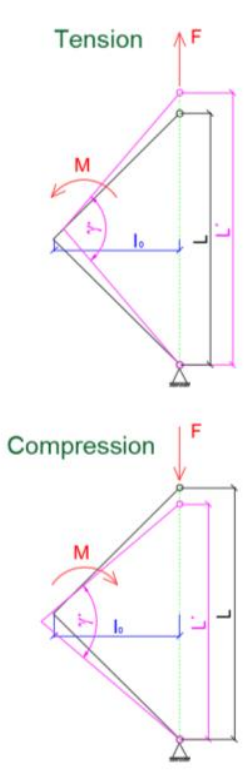

A)

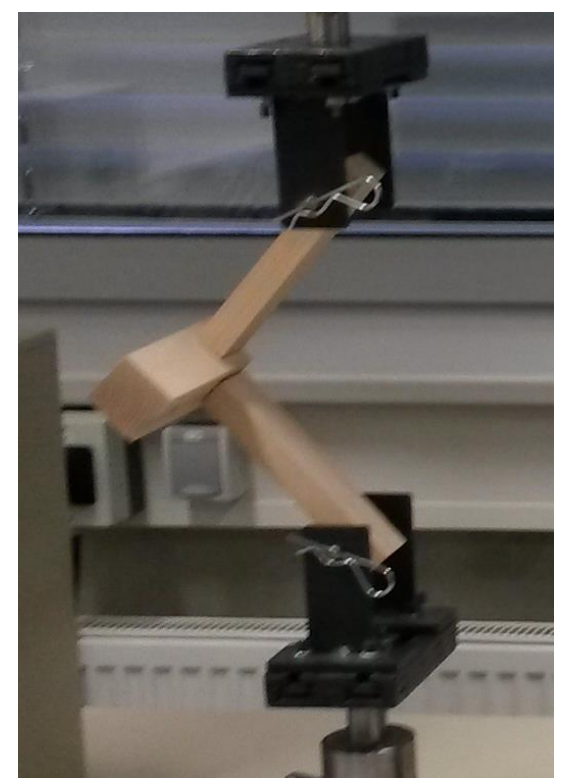

B)

Fig. 10. A) Schematic diagram of the tensile and compressive stress, where the original shape is in black and the deformed shape is in purple; B) Picture of the experimental testing 
According to Eq. 3, the change in the angle between the joint rails $(\Delta \gamma)$ was calculated. To calculate the change in torque, $\Delta M(\mathrm{Nm})$, Eq. 4 was used,

$$
\begin{aligned}
& \Delta \gamma=90 \pm \gamma^{\prime} \\
& \Delta M=\Delta F \cdot l_{0}
\end{aligned}
$$

where $\Delta F$ represents the difference between the two forces that was recorded from the working diagrams (Figs. 11A and 11B) at 10\% to $40 \%$ of the maximum joint strength, and $l_{0}$ represents the vertical arm of the tested joint in the direction of the loading force.

The elastic stiffness, $c_{\text {elast }}(\mathrm{Nm} / \mathrm{rad})$, was calculated according to Eq. 5 as the ratio of the change in torque to the change in angle in radians.

$$
c_{\text {elast }}=\frac{\Delta M}{\Delta \gamma}
$$

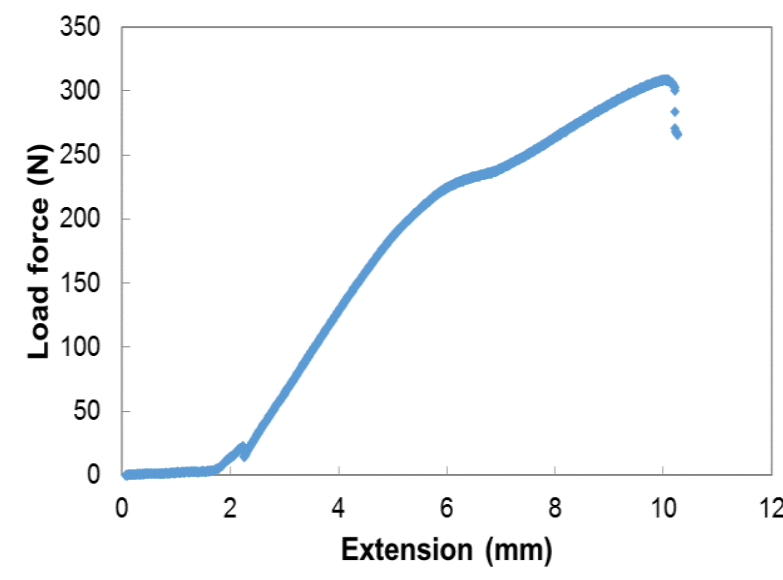

A)

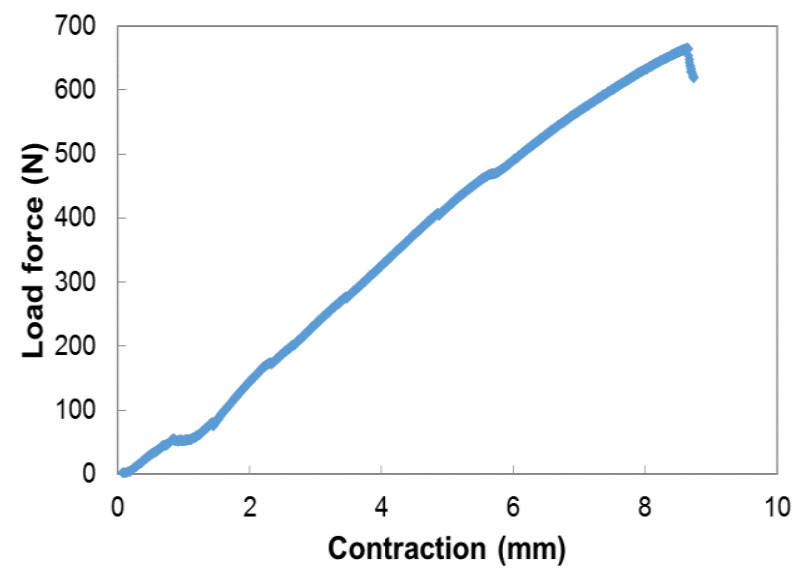

B)

Fig. 11. A) Working diagram of a haunched mortise and tenon joint made from spruce wood glued with PUR adhesive under tensile stress; B) Working diagram of a haunched dovetail mortise and tenon joint made from beech wood glued with PVAc adhesive under compressive stress

The influences of the interaction of factors and individual factors on the elastic stiffness were determined with an analysis of variance (ANOVA) and Fisher's F-test with STATISTICA 12 software (Statsoft Inc., Oklahoma, USA). Based on the P-level value, it was determined whether or not the monitored factor significantly affected the stiffness. The obtained results were illustrated by diagrams showing a $95 \%$ to $99 \%$ confidence interval. The correlation analysis was completed with Excel software (Microsoft, Seattle, USA).

\section{RESULTS AND DISCUSSION}

Table 2 shows the average values of the density and elastic stiffness determined for individual sets of the specimens with a simple mortise and tenon joint. The average density of the beech specimens with a $12 \%$ moisture content was $0.743 \mathrm{~g} / \mathrm{cm}^{3}$. This value corresponds with the values listed in the scientific literature. Wagenführ (2000) indicated a $0.720 \mathrm{~g} / \mathrm{cm}^{3}$ density of beech wood with a $12 \%$ moisture content, and Požgaj et al. (1997) found a density of $0.712 \mathrm{~g} / \mathrm{cm}^{3}$. The average density measured in the spruce specimens 
with a $12 \%$ moisture content during the experiment was $0.428 \mathrm{~g} / \mathrm{cm}^{3}$. This measurement corresponds with the information provided in the scientific literature. Požgaj et al. (1997) indicated a $0.421 \mathrm{~g} / \mathrm{cm}^{3}$ density for spruce wood with a $12 \%$ moisture content. Wagenführ (2000) reported a value of $0.470 \mathrm{~g} / \mathrm{cm}^{3}$. The density of the beech specimens was $74 \%$ higher than for the spruce specimens.

The highest average elastic stiffness value of $1503 \mathrm{Nm} / \mathrm{rad}$ was achieved in the beech specimens using the PVAc adhesive and half-joint thickness. The lowest average value of $613 \mathrm{Nm} / \mathrm{rad}$ was measured in the spruce specimens using the one-third joint thickness and PUR adhesive. On average, the elastic stiffness of the beech joints was $30 \%$ higher than the elastic stiffness of the spruce joints.

Table 2. Average Density and Stiffness Values of the Haunched Mortise and Tenon Joints with their Coefficients of Variation

\begin{tabular}{|c|c|c|c|c|c|}
\hline \multirow{2}{*}{$\begin{array}{c}\text { Type of } \\
\text { Loading }\end{array}$} & \multirow{2}{*}{$\begin{array}{c}\text { Wood } \\
\text { Species }\end{array}$} & \multirow{2}{*}{$\begin{array}{c}\text { Joint } \\
\text { Thickness }\end{array}$} & \multirow{2}{*}{$\begin{array}{c}\text { Adhesive } \\
\text { type }\end{array}$} & $\begin{array}{c}\text { Density } \\
\left(\mathbf{g} / \mathbf{c m}^{3}\right)\end{array}$ & $\begin{array}{c}\text { Elastic Stiffness } \\
\text { (Nm/rad) }\end{array}$ \\
\hline \hline Compression & Spruce & Third & PVAc & $0.456(7.8)$ & $812(22.7)$ \\
\hline Compression & Spruce & Half & PVAc & $0.418(6.8)$ & $785(17.2)$ \\
\hline Compression & Beech & Third & PVAc & $0.747(2.3)$ & $1213(14.1)$ \\
\hline Compression & Beech & Half & PVAc & $0.732(2.2)$ & $1503(23.1)$ \\
\hline Tension & Spruce & Third & PVAc & $0.418(7.2)$ & $737(17.9)$ \\
\hline Tension & Spruce & Half & PVAc & $0.452(5.5)$ & $908(16.2)$ \\
\hline Tension & Beech & Third & PVAc & $0.744(1.7)$ & $1206(29.1)$ \\
\hline Tension & Beech & Half & PVAc & $0.739(2.4)$ & $1458(21.8)$ \\
\hline Compression & Spruce & Third & PUR & $0.431(6.3)$ & $751(15.5)$ \\
\hline Compression & Spruce & Half & PUR & $0.446(8.6)$ & $1039(11.0)$ \\
\hline Compression & Beech & Third & PUR & $0.751(2.5)$ & $1011(29.4)$ \\
\hline Compression & Beech & Half & PUR & $0.730(2.0)$ & $1136(31.5)$ \\
\hline Tension & Spruce & Third & PUR & $0.435(8.8)$ & $613(39.6)$ \\
\hline Tension & Spruce & Half & PUR & $0.422(6.2)$ & $924(26.3)$ \\
\hline Tension & Beech & Third & PUR & $0.758(2.2)$ & $784(13.0)$ \\
\hline Tension & Beech & Half & PUR & $0.727(1.3)$ & $855(33.6)$ \\
\hline
\end{tabular}

Values in parentheses are coefficients of variation (CV, \%)

Table 3 shows the average values of the density and elastic stiffness for all of the tested sets of specimens with the dovetail mortise and tenon joint.

The average elastic stiffness of the beech joints was $1543 \mathrm{Nm} / \mathrm{rad}$. A $636 \mathrm{Nm} / \mathrm{rad}$ average stiffness for the spruce joints was determined. The average elastic stiffness of the beech joints was $141 \%$ higher than the stiffness found in the spruce joints. 
Table 3. Average Density and Stiffness Values of the Haunched Dovetailed Mortise and Tenon Joints with their Coefficients of Variation

\begin{tabular}{|c|c|c|c|c|c|}
\hline \multirow{2}{*}{$\begin{array}{c}\text { Type of } \\
\text { Loading }\end{array}$} & \multirow{2}{*}{$\begin{array}{c}\text { Wood } \\
\text { Species }\end{array}$} & $\begin{array}{c}\text { Joint } \\
\text { Thickness }\end{array}$ & $\begin{array}{c}\text { Adhesive } \\
\text { type }\end{array}$ & $\begin{array}{c}\text { Density } \\
\left(\mathbf{g} / \mathbf{c m}^{3}\right)\end{array}$ & $\begin{array}{c}\text { Elastic } \\
\text { Stiffness } \\
\text { (Nm/rad) }\end{array}$ \\
\cline { 5 - 6 } & & Mean & Mean \\
\hline \hline Compression & Spruce & Third & PVAc & $0.417(6.0)$ & $601(15.7)$ \\
\hline Compression & Spruce & Half & PVAc & $0.421(3.4)$ & $826(12.2)$ \\
\hline Compression & Beech & Third & PVAc & $0.727(2.5)$ & $1519(43.6)$ \\
\hline Compression & Beech & Half & PVAc & $0.739(2.5)$ & $2246(16.4)$ \\
\hline Tension & Spruce & Third & PVAc & $0.409(4.1)$ & $530(28.5)$ \\
\hline Tension & Spruce & Half & PVAc & $0.404(5.5)$ & $722(24.0)$ \\
\hline Tension & Beech & Third & PVAc & $0.733(1.8)$ & $1763(29.5)$ \\
\hline Tension & Beech & Half & PVAc & $0.731(2.5)$ & $2326(11.7)$ \\
\hline Compression & Spruce & Third & PUR & $0.420(8.4)$ & $460(6.6)$ \\
\hline Compression & Spruce & Half & PUR & $0.405(5.5)$ & $767(11.2)$ \\
\hline Compression & Beech & Third & PUR & $0.735(2.8)$ & $1298(22.5)$ \\
\hline Compression & Beech & Half & PUR & $0.732(2.2)$ & $1040(50.2)$ \\
\hline Tension & Spruce & Third & PUR & $0.403(6.8)$ & $465(25.3)$ \\
\hline Tension & Spruce & Half & PUR & $0.405(5.5)$ & $713(21.8)$ \\
\hline Tension & Beech & Third & PUR & $0.741(1.9)$ & $778(31.9)$ \\
\hline Tension & Beech & Half & PUR & $0.733(2.1)$ & $1370(37.0)$ \\
\hline
\end{tabular}

Values in parentheses are coefficients of variation (CV, \%)

Table 4 shows the results of the four-factor ANOVA that assessed the effect on the elastic stiffness of the joint of each factor and their 2-, 3-, and 4-factor interactions.

Table 4. Multifactor Analysis of Variance for Elastic Stiffness of the Wood Joints

\begin{tabular}{|c|c|c|c|c|c|}
\hline Monitored Factor & $\begin{array}{c}\text { Sum of } \\
\text { Squares }\end{array}$ & $\begin{array}{c}\text { Degree of } \\
\text { Freedom }\end{array}$ & Variance & $\begin{array}{c}\text { Fisher's } \\
\text { F-test }\end{array}$ & $\begin{array}{c}\text { Significance } \\
\text { Level }\end{array}$ \\
\hline Intercept & 343608518 & 1 & 343608518 & 3533.563 & $P<0.01$ \\
\hline 1 - Wood species & 30345624 & 1 & 30345624 & 312.065 & $P<0.01$ \\
\hline 2 - Type of joint & 891376 & 1 & 891376 & 9.167 & $P<0.01$ \\
\hline 3 - Joint thickness & 5191241 & 1 & 5191241 & 53.385 & $P<0.01$ \\
\hline 4 - Type of glue & 8282084 & 1 & 8282084 & 85.170 & $P<0.01$ \\
\hline $1^{*} 2$ & 6789539 & 1 & 6789539 & 69.822 & $P<0.01$ \\
\hline $1^{*} 3$ & 130718 & 1 & 130718 & 1.344 & $P=0.25$ \\
\hline $2^{*} 3$ & 389588 & 1 & 389588 & 4.006 & $P=0.05$ \\
\hline $1^{*} 4$ & 7112549 & 1 & 7112549 & 73.143 & $P<0.01$ \\
\hline $2^{*} 4$ & 1423343 & 1 & 1423343 & 14.637 & $P<0.01$ \\
\hline $3^{*} 4$ & 156896 & 1 & 156896 & 1.613 & $P=0.20$ \\
\hline $1^{*} 2^{*} 3$ & 134829 & 1 & 134829 & 1.387 & $P=0.24$ \\
\hline $1^{*} 2^{*} 4$ & 625290 & 1 & 625290 & 6.430 & $P=0.01$ \\
\hline $1^{*} 3^{*} 4$ & 1121655 & 1 & 1121655 & 11.535 & $P<0.01$ \\
\hline $2^{*} 3^{*} 4$ & 270396 & 1 & 270396 & 2.781 & $P=0.10$ \\
\hline $1^{*} 2^{*} 3^{*} 4$ & 26402 & 1 & 26402 & 0.272 & $P=0.60$ \\
\hline Error & 29561379 & 304 & 97241 & & \\
\hline${ }^{*}$ & \multicolumn{3}{|c|}{} \\
\hline
\end{tabular}

Significance was accepted at $P<0.01$ 
The wood species, type of joint, joint size, and type of adhesive were all considered to be statistically significant. The two-factor analyses showed that the interaction of the wood species with the type of joint, and interaction of the type of adhesive with the wood type or type of joint was statistically significant. A three-factor analysis showed that the effect of the interaction of the wood species, joint thickness, and type of adhesive was statisitically significant.

Tables 5 and 6 demonstrate the effect of the loading type and annual ring direction. With a P-value of 0.37 for the loading type and P-value of 0.60 for the direction of the annual rings, it was concluded that both of these factors were statistically insignificant. The results of Záborský et al. (2017) agreed with respect to the loading type, which was considered to be a statistically insignificant factor with a P-value of 0.1 . According to the results of Záborský et al. (2017), the effect of the annual rings was on the borderline of statistical significance with a P-value of 0.05 .

Table 5. One-way Analysis of Variance of the Effect of the Loading Type on the Elastic Stiffness of the Wood Joint

\begin{tabular}{|c|c|c|c|c|c|}
\hline Monitored Factor & $\begin{array}{c}\text { Sum of } \\
\text { Squares }\end{array}$ & $\begin{array}{c}\text { Degree of } \\
\text { Freedom }\end{array}$ & Variance & $\begin{array}{c}\text { Fisher's } \\
\text { F-test }\end{array}$ & $\begin{array}{c}\text { Significance } \\
\text { Level }\end{array}$ \\
\hline Intercept & 343608518 & 1 & 343608518 & 1184.809 & $P<0.01$ \\
\hline Type of loading & 229150 & 1 & 229150 & 0.790 & $P=0.37$ \\
\hline Error & 92223758 & 318 & 290012 & & \\
\hline
\end{tabular}

Significance was accepted at $\mathrm{P}<0.01$

Table 6. One-way Analysis of Variance of the Effect of the Annual Ring Direction on the Elastic Stiffness of the Wood Joint

\begin{tabular}{|c|c|c|c|c|c|}
\hline Monitored Factor & $\begin{array}{c}\text { Sum of } \\
\text { Squares }\end{array}$ & $\begin{array}{c}\text { Degree of } \\
\text { Freedom }\end{array}$ & Variance & $\begin{array}{c}\text { Fisher's } \\
\text { F-test }\end{array}$ & $\begin{array}{c}\text { Significance } \\
\text { Level }\end{array}$ \\
\hline Intercept & 332948282 & 1 & 332948282 & $\begin{array}{c}1145.30 \\
4\end{array}$ & $P<0.01$ \\
\hline $\begin{array}{c}\text { Deflection of annual } \\
\text { rings }\end{array}$ & 298692 & 2 & 149346 & 0.514 & $P=0.60$ \\
\hline Error & 92154217 & 317 & 290707 & & \\
\hline
\end{tabular}

Significance was accepted at $\mathrm{P}<0.01$

Figure 12 demonstrates the effect of the individual factors on the elastic stiffness of the joint. Figure 12A showed that the effect of the wood species was a statistically significant factor. This was also confirmed by a P-value of less than 0.01 , as listed in Table 4. On average, the stiffness value of the beech joints (1332 Nm/rad) was $81 \%$ higher than that of the spruce joints $(733 \mathrm{Nm} / \mathrm{rad})$. These results agreed with the results from Záborský et al. (2017).

Figure 12B presents the effect of the type of joint. With a P-value less than 0.01 , the type of joint was a statistically significant factor in the simple mortise and tenon joints. The average elastic stiffness was $983 \mathrm{Nm} / \mathrm{rad}$. The dovetail mortise and tenon joints exhibited an elastic stiffness of $1098 \mathrm{Nm} / \mathrm{rad}$; therefore, this type of joint achieved 10\% higher stiffness values. 
A)

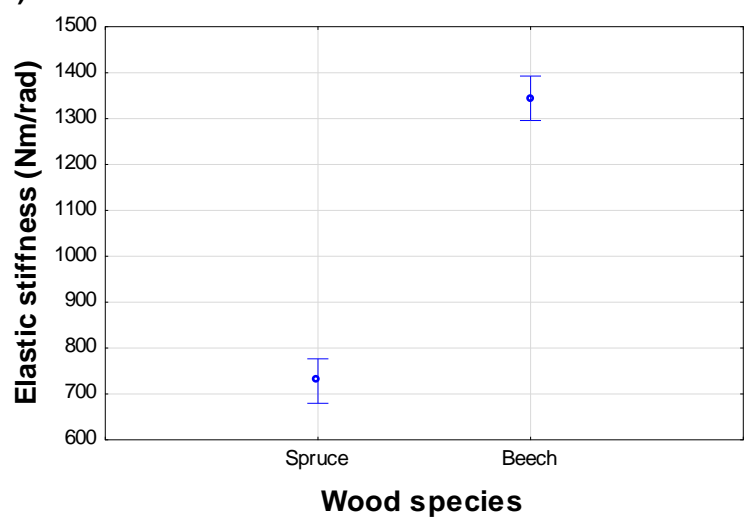

C)

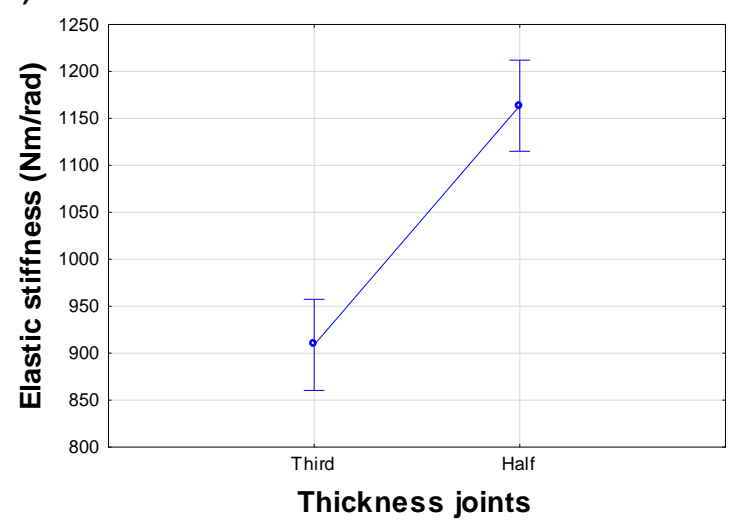

E)

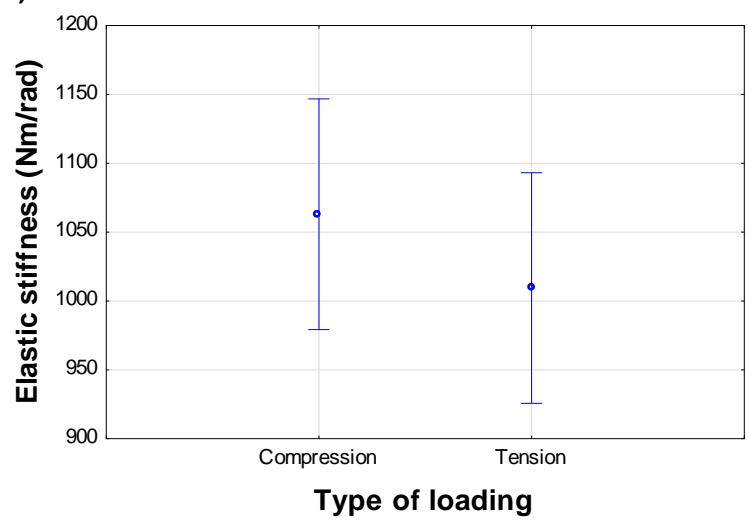

B)

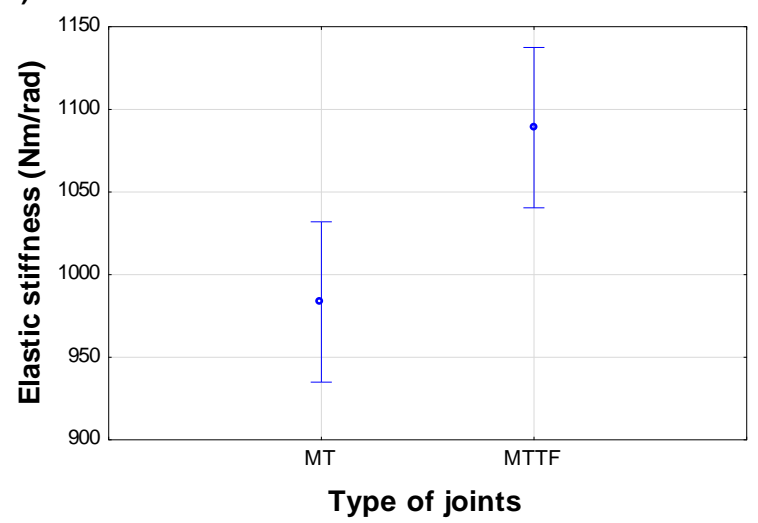

D)

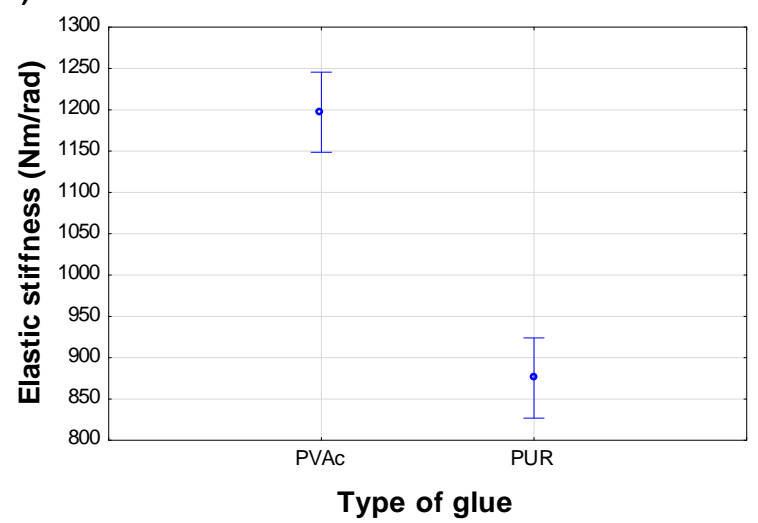

F)

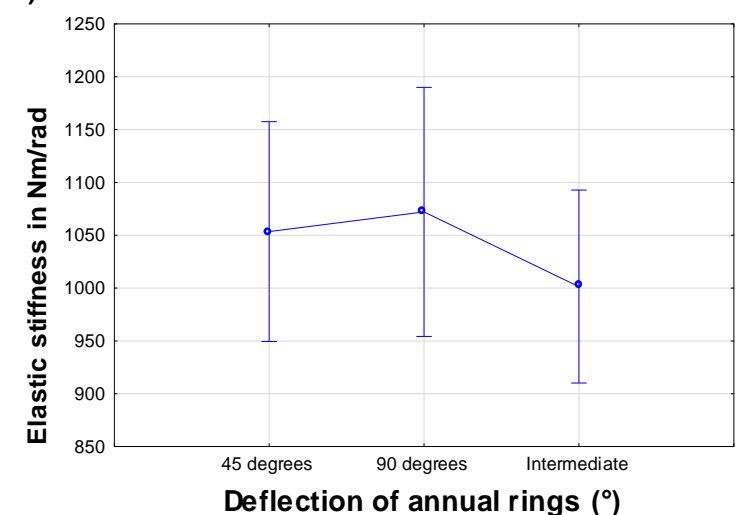

Fig. 12. Graphic visualization of the effect of wood species $(A)$, type of joint (B), thickness of joint $(C)$, type of glue (D), type of loading (E), and deflection of annual rings (F) on the elastic stiffness; MT $=$ Mortise and tenon, MTTF $=$ Mortise and tenon with a toothed feather

Figure $12 \mathrm{C}$ reflects the effect of the thickness of the joint. Thicker mortises and tenons showed a $28 \%$ higher elastic stiffness. The average stiffness of the joints with a half thickness was $1163 \mathrm{Nm} / \mathrm{rad}$. The average stiffness of the joints with a one-third thickness was $908 \mathrm{Nm} / \mathrm{rad}$. This positive effect from the joint thickness was also confirmed by Záborský et al. (2017) and Derikvand and Ebrahimi (2014). Záborský et al. (2017) compared the same joint thicknesses that were studied in this research, $8 \mathrm{~mm}$ and $12 \mathrm{~mm}$. 
In thicker joints, Záborský et al. (2017) measured an elastic stiffness that was up to $43 \%$ higher for the structure. Derikvand and Ebrahimi (2014) compared 6- and 8-mm tenons. Oktaee et al. (2014) compared various mortise and tenon thicknesses, namely $37.5 \mathrm{~mm}$ mortise thickness, and $25 \mathrm{~mm}$ and $50 \mathrm{~mm}$ tenon thicknesses. As the thickness and length of the joint increased, the strength and stiffness of the joint also increased.

Figure 12D clearly showed that the effect of the adhesive was statistically significant. A stronger joint was created using the PVAc adhesive with an average stiffness of $1197 \mathrm{Nm} / \mathrm{rad}$. In contrast, the stiffness values were lower when the PUR adhesive was used, giving an average stiffness of $875 \mathrm{Nm} / \mathrm{rad}$. These results correspond with the results obtained in the research conducted by Záborský et al. (2017).

Figures $12 \mathrm{E}$ and $12 \mathrm{~F}$ showed that the effect of the loading type and annual ring direction, respectively, were statistically insignificant. No statistically significant difference was proven between the tensile and compressive stress. According to a fourfactor analysis, the direction of the annual rings was statistically insignificant.

Figure 13 shows a graphical representation of the correlation between the stiffness and density. There was a distinct upward trend, which showed the significantly higher variability of the stiffness of the beech joints; whereas in the spruce joints, this factor was not as significant.

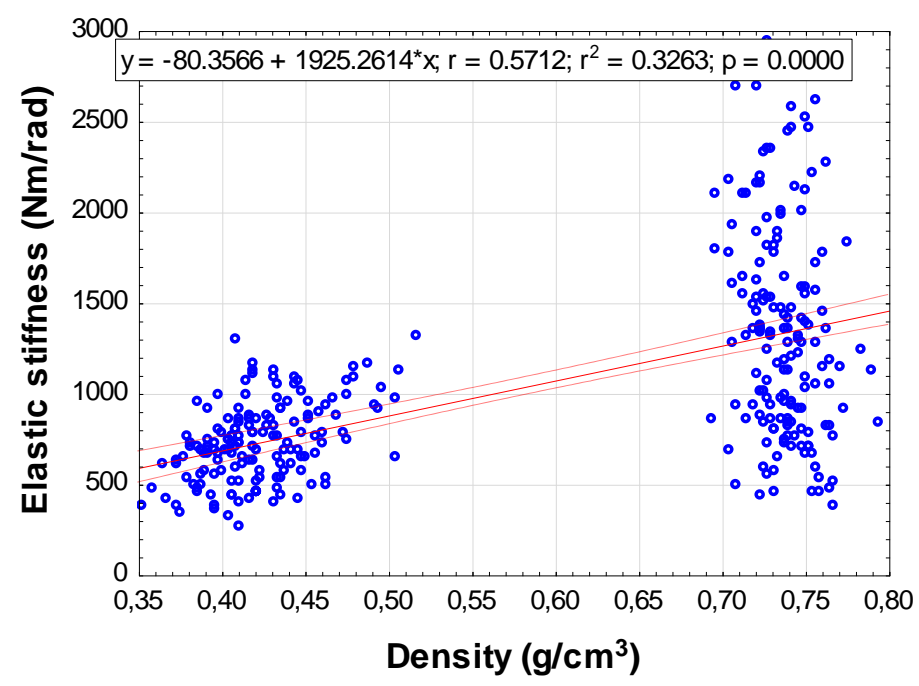

Fig. 13. Dependence of the elastic stiffness on the density of the wood joints

The graphs in Fig. 14 show that there was a difference in the stiffness of the onethird and half-joint thicknesses, although it was not statistically significant overall. There was a significant increase in the stiffness, particularly in the beech dovetail joints with half thickness (approximately 30\%).

The effect of this factor was more interesting after incorporating the effect of the type of adhesive. There was an overall statistically significant difference between the stiffness of the joints bonded with the PVAc and PUR adhesives. Figures 15 and 16 showed that the specimens glued with the PUR adhesive achieved a lower stiffness. This corresponds with the results of Záborský et al. (2017).

The graphs in Fig. 15 showed that the difference in the spruce joints was not significant at all, but was significant in the beech joints, where there was a higher stiffness in the joints glued with PVAc. The increase in the stiffness of the MT was approximately $42 \%$, and the stiffness increase was approximately $75 \%$ in the MTTF. 


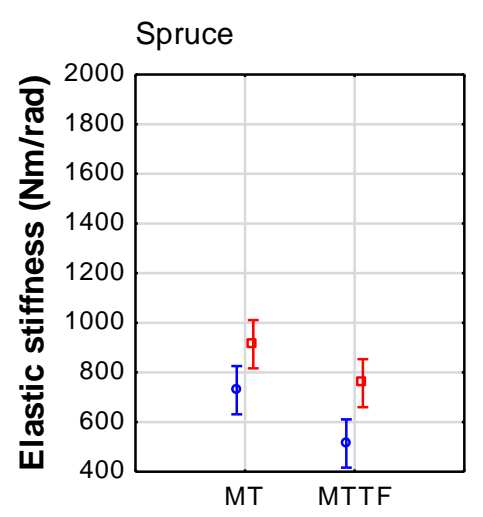

Type of joint

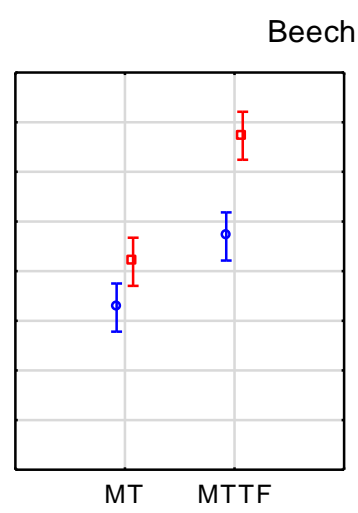

Type of joint

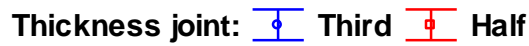

Fig. 14. Influence of the interaction of wood species, type of joint, and joint thickness on the stiffness
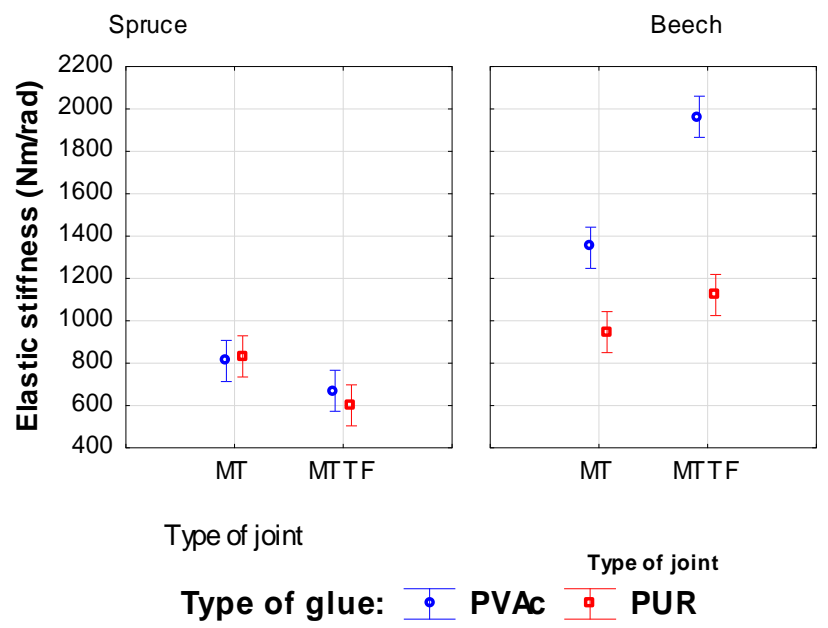

Fig. 15. Influence of the interaction of the wood species, type of joint, and type of glue on the stiffness; MT = Mortise and tenon, MTTF = Mortise and tenon with a toothed feather
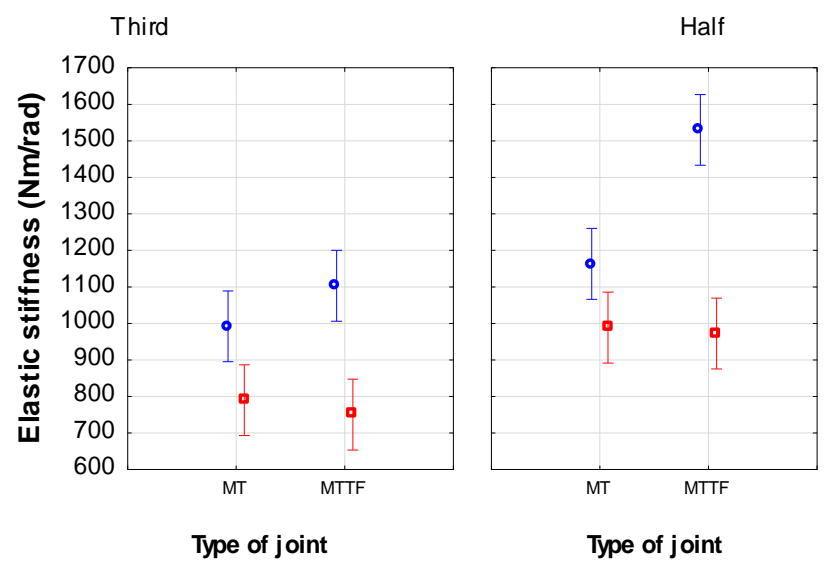

Type of glue: $\Phi$ PVAc 平PUR

Fig. 16. Influence of the interaction of the thickness joint, type of joint, and type of glue on the stiffness; MT = Mortise and tenon, MTTF = Mortise and tenon with a toothed feather 
Figure 16 shows that the type of joint did not have a significant effect for the joints glued with PUR, where the joint thickness caused an increase of approximately $27 \%$ in the stiffness. For the joints glued with PVAc, both the thickness and type of joint were important. For example, in the half-thick dovetail mortise and tenon joint, there was an approximately $32 \%$ increase in comparison with the ordinary mortise and tenon joint.

\section{CONCLUSIONS}

1. In the spruce specimens with a dovetail joint, the stiffness decreased approximately $21 \%$. In the beech specimens, the use of a dovetail joint had a significant effect. In comparison with a simple mortise and tenon joint, the stiffness increased by an average of $41 \%$.

2. The greater joint thickness, i.e. half-thick joint, was shown to be a statistically significant factor in all cases. The use of a thicker joint resulted in an increase in the stiffness. Using a joint with a simple dovetail caused an average increase of $16 \%$ in the spruce specimens. The use of a simple dovetail joint caused an increase of $68 \%$ in the beech specimens. These results corresponded with the information given in the scientific literature. As the thickness and length of the joint increased, the strength and stiffness of the joint also increased.

3. The effect of the type of adhesive was statistically insignificant in the spruce joints. In the joints made with beech using PVAc glue, the joint stiffness was significantly higher than with the use of PUR glue. The stiffness increased in MT approximately $42 \%$, in MTTF approximately $75 \%$.

4. The loading type had no statistically significant effect on the stiffness of the joints, although certain trends were apparent. The tensile strength was somewhat lower. The effect of the annual ring direction was also statistically insignificant. However, a trend where the highest values were achieved for the samples with annual rings forming a $90^{\circ}$ angle in the joint was identified.

5. The evaluation of these two joints, i.e. the simple joint of the mortise - tenon (MT) and the mortise and tenon with the toothed feather (MTTF), was carried out as a follow-up study after an evaluation of joints of the mortise and tenon with feather (MTF) type (see Záborský et al. 2017). The MTTF can be regarded as an improved version of the MTF joint. For spruce, the use of MTTF joints was found to be disadvantageous (stiffness decrease of about $21 \%$ ), whereas in beech the use of the toothed feather was favorable (stiffness increase of about 41\%). The other two types of joints (MT and MTF) were more or less equivalent in terms of stiffness for both types of wood, which implies that it is not important to incorporate feathering features into the design of such joints. Half thickness of the joint (joint type, type of wood, ...), in any case, is always an advantage, the stiffness increases in the range of about $16 \%$ (for Spruce-MTF) to about $68 \%$ (for Beech-MTF). Generally, for spruce joints, it the kind of glue employed was not important, whereas for beech joints, in all cases, the stiffness of joints glued with PVAc was significantly higher than with PUR adhesive. 


\section{ACKNOWLEDGMENTS}

The authors are grateful for the support of the University-wide Internal Grant Agency (CIGA) of the Faculty of Forestry and Wood Sciences, project No. 2016 - 4311.

\section{REFERENCES CITED}

BS EN 789:2004 (2005). "Timber structures - Test methods - Determination of mechanical properties of wood-based panels," British Standards Institution, London, UK.

Derikvand, M., and Ebrahimi, G. (2014). "Strength performance of mortise and loosetenon furniture joints under uniaxial bending moment," J. Forest. Res. 25(2), 483486. DOI: 10.1007/s11676-014-0479-5

Erdil, Y. Z., Kasal, A., and Eckelman, C. A. (2005). "Bending moment capacity of rectangular mortise and tenon furniture joints," Forest Prod. J. 55(12), 209-213.

Gaff, M., Ruman, D., Borůvka, V., and Záborský, V. (2016). "Impact bending strength as a function of selected factors," BioResources 11(4), 9880-9895. DOI: 10.15376/biores.11.4.9880-9895

Horman, I., Hajdarevič, S., Martinovič, S., and Vukas, N. (2010). "Numerical analysis of stress and strain in a wooden chair," Drvna Industrija 61(3), 151-158.

ISO 13061-1:2014 (2014). "Physical and mechanical of wood - Test methods for small clear wood specimens - Part 1: Determination of moisture content for physical and mechanical tests," International Org. for Standardization, Geneva, Switzerland.

ISO 13061-2:2014 (2014). "Physical and mechanical of wood - Test methods for small clear wood specimens - Part 2: Determination of density for physical and mechanical tests," International Organization for Standardization, Geneva, Switzerland.

ČSN 910000 (2005), "Furniture - Nomenclature," International Organization for Standardization, Geneva, Switzerland.

ČSN 910001 (2007), "Wooden furniture, - Technical requirements," International Organization for Standardization, Geneva, Switzerland.

ČSN EN 942 (2007), "Wood for joinery products - General requirements, - Technical requirements," International Organization for Standardization, Geneva, Switzerland.

Kasal, A., Havierova, E., Efe, H., Eckelman, C. A., and Erdil, Y. Z. (2013). "Effect of adhesive type and tenon size on bending moment capacity and rigidity of T-shaped furniture joints constructed of Turkish beech and Scots pine," Wood Fiber Sci. 45(3), 287-293.

Kasal, A., Koşkun, T., Efe, H., and Erdil, Y. Z. (2015). "Relation between static front to back loading capacity of whole chair and the strength of individual joints," in: $27^{\text {th }}$ International Conf. Research for Furniture Industry, Ankara, Turkey, pp. 422-429.

Kasal, A., Smardzewski, J., Kuşkun, T., and Erdil, Y. Z. (2016). "Numerical analyses of various sizes of mortise and tenon furniture joints," BioResources 11(3), 6836-6853. DOI: 10.15376/biores.11.3.6836-6853

Kubš, J., Gaff, M., and Barcík, Š. (2016). "Factors affecting the consumption of energy during the milling of thermally modified and unmodified beech wood," BioResources 11(1), 736-747. DOI: 10.15376/biores.11.1.736-747

Kvietková, M., Gaff, M., Gašparík, M., Kaplan, L., and Barcík, Š. (2015a). "Surface quality of milled birch wood after thermal treatment at various temperatures," BioResources 10(4), 6512-6521. DOI: 10.15376/biores.10.4.6512-6521 
Kvietková, M., Gašparík, M., and Gaff, M. (2015b). "Effect of thermal treatment on surface quality of beech wood after plane milling," BioResources 10(3), 4226-4238. DOI: 10.15376/biores.10.3.4226-4238

Miftieva, E., Gaff, M., Svoboda, T., Babiak, M., Gašparík, M., Ruman, D., and Suchopár, M. (2016). "Effect of selected factors on bending characteristics of beech wood," BioResources 11(1), 599-611. DOI: 10.15376/biores.11.1.599-611

Noll, T. (2009). Joint Book: The Complete Guide to Wood Joinery, Chartwell Books, Edison, NJ.

Nutsch, W., Eckerhard, M., Ehrmann, W., Hammerl, W., Hammler, D., Nestle, H., Nutsch, T., and Schulz, P. (2006). Přiručka Pro Truhláre [Carpenter's Guide], Europa Editions, Prague, Czech Republic.

Oktaee, J., Ebrahimi, G., Layeghi, M., Ghofrani, M., and Eckelman, C. A. (2014). "Bending moment capacity of simple and haunched mortise and tenon furniture joints under tension and compression load," Turkish Journal of Agriculture and Forestry 38(2), 291-297. DOI: 10.3906/tar-1211-74

Osten, M. (1996). Práce s Lepidly a Tmely [Work with Adhesives and Fillers], Grada, Prague, Czech Republic.

Požgaj, A., Chovanec, D., Kurjatko, S., and Babiak, M. (1997). Štruktúra a Vlastnosti Dreva [Structure and Properties of Wood], Príroda, Bratislava, Slovakia.

Ruman, D., Gaff, M., Gašparík, M., and Babiak, M. (2016). "Experimental evaluation of joints using thin steel angles for wood structures," BioResources 11(1), 33-43. DOI: 10.15376/biores.11.1.33-43

Sabareth, A. (2014). "Eight types of wood joints," (https://blog.udemy.com/types-of wood-joints/), Accesed 1 January 2017.

Sedliačik, M., and Sedliačik, J. (1998). Chemické Látky v Drevárskom Priemysle [Chemical Substances in Wood Industry], Zvolen Technicla Univ., Zvolen, Slovakia.

Sumiyoshi, T., and Matsui, G. (1989). Wood Joints in Classical Japanese Architecture, Kajima Institute Publishing Co. Ltd., Tokyo, Japan.

Svoboda, T., Ruman, D., Gaff, M., Gašparík, M., Miftieva, E., and Dundek, L. (2015). "Bending characteristics of multilayered soft and hardwood materials," BioResources 10(4), 8461-8473. DOI: 10.15376/biores.10.4.8461-8473

Tankut, A. N., and Tankut, N. (2005). "The effects of joint forms (shape) and dimensions on the strength of mortise and tenon joint," Turkish Journal of Agriculture and Forestry 29(6), 493-498.

Tankut, N. (2007). "The effect of adhesive type and bond line thickness on the strength of mortise and tenon joints," Int. J. Adhes. Adhes. 27(6), 493-498. DOI: 10.1016/j.ijadhadh.2006.07.003

Wagenführ, R. (2000). Holzatlas [Atlas of Wood], Fachbuchverlag, Leipzig, Germany.

Záborský, V., Borůvka, V., Ruman, D., and Gaff, M. (2017). "Effects of geometric parametres of structural elements on joint stiffness," BioResources 12(1), 932-946. DOI: 10.15376/biores.12.1.932-946

Article submitted: April 6, 2017; Peer review completed: July 22, 2017; Revised version received: August 2, 2017; Published: August 7, 2017.

DOI: $10.15376 /$ biores.12.4.7016-7031 